\section{Zabarella, Jacopo}

Born: 5 September 1533, Padua

Died: 15 October 1589, Padua

Marco Sgarbi

Ca' Foscari University of Venice, Venice, Italy

\section{Abstract}

Jacopo Zabarella (1553-1589) is considered one of the most acute and brilliant logicians of all time. He made an important contribution to the interpretation of Aristotle and developed original ideas especially in the field of logic and epistemology, opening up the pathway of early modern science.

\section{Biography}

He was born in Padua on 5 September 1533, the eldest son of Giulio Zabarella. He was well-versed in Latin and Greek from childhood, as one of his letters to the praetor of Padua demonstrates. He studied at the University of Padua, where he graduated on 19 June 1553, supervised by Marco Antonio Genova (1491-1563), who was professor of natural philosophy. He studied logic with Bernardino Tomitano (1517-1576), Latin and Greek with Francesco Robortello (1516-1567), and mathematics with Pietro Catena (1501-1576). On 13 January 1564 he was appointed to the first chair of logic, succeeding Tomitano. On 4 January 1569 he secured the second extraordinary chair of natural philosophy. There was likely a pause in his teaching from 1574 to 1576 on account of the severity of plague in Padua. On 26 March 1577 he acquired the first extraordinary chair of natural philosophy, and in 1578, he published his Opera logica in Venice, thus opening a large debate on the order and method of knowledge among his contemporaries - especially with Francesco Piccolomini (1520-1604) and Bernardino Petrella (1529-1595). In 1580 Zabarella published his Tabulae logicae and also founded the Accademia degli Stabili. In 1584, he came under attack in two directions: from Piccolomini in his Universa philosophia de moribus, and from Petrella in his Logicarum disputationum libri VII. The same year, Zabarella's reply to Piccolomini was his De doctrina ordine apologia. In the meantime, on 6 September 1585, he became professor of the second ordinary chair of natural philosophy, and the following year he published his De naturalis scientiae constitutione. In 1584, Ascanio Persio (1554-1610), a student of Zabarella, had replied to Petrella's charges in his Logicarum exercitationum libri II, to which Petrella himself responded with his Propugnatio, Persio re-engaging again in 1587 with his Defensiones criticorum et apologetici primi adversus Bernardini Petrellae logicam. Zabarella died in Padua on 15 October 1589. Five years later, in 1594, Piccolomini countered the Apologia with his Comes politicus pro recta ordinis ratione 
propugnator. During Zabarella's lifetime, the Opera logica went through at least three different editions $(1578,1586,1587)$, and after his death there were eleven further editions $(1591,1594$, 1597, 1599, 1600, 1602, 1603, 1604, 1608, 1617, 1623). The Tabulae logicae was published five times $(1580,1583,1586,1587,1589)$ in the decade before his death, and subsequently became part of the Opera logica. The commentary to the Analytica posteriora was published in 1582 and 1587, and appeared thereafter in the Opera logica. The Apologia de doctrinae ordine was published twice in Zabarella's life - in 1584 and 1587 - and then a further four times $(1594,1595,1599,1604)$, before becoming part of the Opera logica. The De rebus naturalibus libri triginta was brought together after Zabarella's death, and went through ten editions (1590, 1591, 1594, 1597, 1601, 1604, 1606, 1607 , 1617, 1654). The treatise De naturalis scientiae constitutione, which was a part of the De rebus naturalibus, went into a separate edition in 1586. The Commentarii in tres libros De Anima underwent four editions (1605, 1606, 1619, 1647). The Commentarii in libros Physicorum (I, II, VIII) was published in 1601 and 1602, with the Commentarii in libros de Generatione et Corruptione, et Meteorologica appearing in 1602. The year 1602 additionally saw the publication of the treatises De Augmentatione and De Putrefactione illa, qua Vinum vertitur in Acetum.

\section{Heritage and Rupture with the Tradition}

Zabarella is one of the main exponents of so-called Paduan Aristotelianism and has been considered one of the most faithful interpreters and commentators of Aristotle. His exegesis is grounded in the reappraisal of ancient Greek commentators like Simplicius, Alexander of Aphrodisias, and Themistius. Yet, Zabarella cannot be characterized a pedantic follower of Aristotelian doctrines and in his works he firmly distinguishes the role of the philosopher from that of commentator (Randal 1961; Poppi 1972; Risse 1983; Mikkeli 1992).

In his 1568 Praelectio, Zabarella points out the duties and limitations of the commentator. He views a commentator as someone "who transmits to others the knowledge received from another, not as his own, but as that he received from another" (Bibl. Ambrosiana, Ms. D 360 Inf., 1v; cf. Bouillon 2009, 461-72). The commentator simply teaches what he has passively learned from other philosophers and discovers no new knowledge. Thus, the commentator is also named interpreter, because in general interpretation is "knowledge transmitted as received from another as such." The commentator is always inferior to the commented author because otherwise he would teach "his science rather than that of another" (Ms. D 360 Inf., 2v). The commentator must recognize his peculiar inferiority, and for this reason "interpretation involves a certain form of servitude, and the interpreter is a servant (interpres servus est)" (Ms. D 360 Inf., 2v). Zabarella is critical of this kind of attitude toward knowledge, maintaining that this kind of servitude "is in itself very undesirable" (Ms. D 360 Inf., 3r). The commentator cannot recognize the truth by himself and needs to appropriate knowledge from the best philosophers. However, no good is greater than to acquire knowledge by one's own effort (Ms. D 360 Inf., 3r). Someone who teaches his own knowledge is not a commentator but a real philosopher (Ms. D 360 Inf., 1v) and aspires to acquire truth. So, a real philosopher, dealing with Aristotle's writings, should make it clear that some of Aristotelian doctrines are erroneous (Ms. D 360 Inf., 4r) - or else he provides a great disservice to the advancement of knowledge. Yet in his 1585 Praelectio, instead, Zabarella writes that a real philosopher is one who investigates the causes of things, working in the first instance directly with sensation and reasoning, and not relying on the authority and words of others. His view is that this is Aristotle's most compelling thesis (Dal Pra 1966, 288). Zabarella criticizes those alleged philosophers holding ideas that are "incompatible with sensation and natural reason" (Dal Pra 1966, 288). He emphasizes the fundamental role that empirical observation plays in scientific cognition, and stresses how reason, and not Aristotle, is the ultimate foundation of science (Schmitt 1983, 11). Aristotle "despised neither sensation nor reason, but harmonizing reason 
with sensation and sensation with reason, and relying on the most solid foundations derived from sensation, he sought to penetrate the secret nature of each thing" (Dal Pra 1966, 289). Zabarella states that one should imitate Aristotle, and he writes that someone is an "imitator of Aristotle and a true Peripatetic because he follows his rule instead of his words" (Dal Pra 1966, 289-90). The rule sets aside probable opinions or conjectures that do not lead to epistemic knowledge in order to focus on demonstrative arguments based on sensation. Thus Zabarella can state that "I will never be satisfied with Aristotle's authority alone to establish something, but I will always rely upon reason; such a thing is truly both natural and philosophical for us, and I will also seem to imitate Aristotle in using reason, for in fact he seems never to have put forward a position without using reason" (Dal Pra 1966, 290). Equally, Zabarella rejects the slavish attachment of Aristotle's commentator to the philosopher's word. One should not disdain to contradict his opinions or the ideas, "quando ratio cogerit" (Dal Pra 1966, 290). For Zabarella, therefore, Aristotelian ideas are valid not because they are "Aristotelian," but because after careful scrutiny by the court of reason they are proven to be true (Palmieri 2007).

\section{Innovative and Original Aspects}

Zabarella's greatest contribution to the history of logic is his instrumental conception of logic and his theory of scientific method (Vasoli 2011). He reached the conclusion that logic is an instrument through an examination of the various disciplines, of their subjects and aims. He proceeded from the recognition of the existence of two kinds of things, those necessary and eternal and those contingent. Necessary and eternal things are not under the mind's control and their causes must be sought beyond the human will. They are the subject of "contemplative disciplines," that is, theoretical sciences which search for the causes of things (divine philosophy or metaphysics, natural philosophy, and mathematics). Contingent things, by contrast, are under the mind's control, will and activity, and form the subject of operative disciplines. These latter cannot be considered either science or wisdom, because both deal in different ways with necessary things, whereas operative disciplines like ethics and poetics deal rather with prudence and art. Zabarella's aim is to show that logic is neither a contemplative nor an operative discipline. To demonstrate this, he makes a distinction between "first notions" (primae notiones) and "second notions" (secundae notiones). Logic deals only with "second notions," which are also called mental concepts. The "first notions" are subject to investigation by the philosopher (i.e., the natural philosopher), and these are concepts that immediately designate real things independent of the power and activity of the mind. They are always concepts, not things, although they refer to and directly mirror things, and this means that the natural philosopher never deals directly with things, even if he describes how things are. The natural philosopher deals with concepts that directly characterize things and aims for explanatory strategies to explain them. The "second notions," on the other hand, derive from "first notions." They are products of the mind in the exercise of its cognitive faculties. The main difference between "first notions" and "second notions" is that "first notions" designate things as they are, while "second notions" concern things as they are known and conceived in the mind - that is, they describe reality as it is thought to be. Zabarella gives an example that comes from the Analytica posteriora II.19: if we know Socrates, Plato, and Callias through perception, the mind forms a common concept of "man," which is the concept of the thing (conceptus rei), that is, a first notion. When we are aware that the concept of "man" is the concept of every individual with the characteristics belonging to the concept of "man," the concept itself becomes a species, that is a second notion. Given that "second notions" are a product of the mind according to its own will, and therefore contingent, they cannot be the subject of science, because science deals only with necessary things. For this reason, logic cannot be a science, but Zabarella also denies that it is an art. With an art, the result of an operation is distinct from the operator and it is often associated 
with matter, while logical operations are entirely immanent in the mind. Zabarella therefore defines logic as an instrumental discipline or habit - in particular, the habit concerning "second notions." It teaches us how to order concepts in the mind and how to acquire new knowledge.

Having defined the nature of logic, Zabarella's pivotal epistemological problem is to solve the question of how scientific knowledge is possible, starting with an examination of the cognitive powers of the mind. In De tribus praecognitis Zabarella deals with the conditions of the mind in acquiring scientific knowledge as put forward by Aristotle in Posterior Analytics. Zabarella states that the object of speculative science is twofold: the first - the material aspect - is the res considerata, while the second - the formal aspect - is the modus considerandi. In the Aristotelian framework science exclusively concerns necessary things, and since matter is always contingent and accidental, science is concerned only with the form - that is, the modus considerandi which is a priori to the object of knowledge (res considerata) and makes it knowable, whatever it is. Scientific investigation, therefore, is an examination of the condition of possibility for cognition in relation to a possible object in general. The conditions of possibility for cognition are what Zabarella calls pre-cognitions (praecognita). Since the speculative science is preceded by precognition, to investigate the condition of possibility for cognition with respect to an object amounts simply to investigating these pre-cognitions. But again, pre-cognition, on which the speculative science is based, cannot be accidental, otherwise scientific knowledge would ultimately be accidental too. Pre-cognition must be grounded in principles that are primary, true, and immediate that is, in logical principles that make cognition possible. Investigating the condition of possibility for cognition in general means, therefore, investigating the first principles of the sciences.

There are various first principles that are not demonstrable but for the purpose of demonstration and they are acquired thorough the senses. Zabarella explains that the knowledge of principles is acquired by means of induction beginning from sensible knowledge. Induction, however, should not be understood as a syllogism that demonstrates unknown things by means of prior knowledge, but as a process that notifies the transition of knowledge of one and the same thing from sensation to the intellect. Ultimately, induction is the process by which particulars are comprehended under the general concept, but properly speaking it does not create new knowledge beyond what the mind has already acquired through sensation.

Sensible knowledge is the foundation for science, but it is not science itself. Indeed, sensible knowledge must first become intellectual knowledge to form then the basis of science, and this is made possible only by the passage of the sensible object - at first as images and then as an intelligible object - through a process of intellection. The transition from sensible to intelligible object is guaranteed both by the continuity of the process of knowledge and also by the subordination of the faculties of the mind. In other words, what is apprehended by sensation, the lowest faculty of knowledge - that is, the singular object - is apprehended also by imagination, a higher faculty of knowledge. The difference between sensation and imagination is that the former always works in the presence of the object, while the latter works in its absence. In turn, what is apprehended by imagination is also apprehended by the highest faculty, the intellect. Therefore, the sensible object is contained through its image in the intelligible object, and the intellect can thereby know the singular concrete object. The difference between sensation, imagination, and intellect lies in the fact that the latter acquires universal knowledge, from which the other two faculties are precluded.

Zabarella's method is grounded on sensation, which provides all knowledge to the intellect, which means that method is the process of discovery through sensation what is most knowable by nature, namely the causes of things and universal concepts. In order to make his conception clear, Zabarella distinguishes the real method of learning from the order of learning. Such a distinction is fundamental to the difference between Zabarella and his follower's conception of method, and that of Platonic scholars and Ramists. Zabarella states that method is a logical 
instrument leading to the discovery of something unknown, while order is not an inferential process, but simply an arrangement of knowledge. In other words, order is not method: the former "arranges," while the latter "notifies" or provides knowledge. Method discovers new knowledge; order does not. In starting with what is more knowable to us - that is, sensible knowledge Zabarella rejects the common assumption of humanistic logic that it is always necessary to start from what is primary in nature. Zabarella is clearly distinguishing an ontological order from an epistemological order. His science rests on logic and epistemology, whose interest is limited to explaining the things that appear to the senses.

Method for Zabarella can be either resolutive (analytic) or compositive (synthetic or demonstrative). The analytic method proceeds from effects to causes, while the synthetic proceeds from first causes to effects. The synthetic method is superior to the analytic because its demonstrative power is superior, starting from the knowledge of causes; indeed, the analytic method "serves" the synthetic method. In particular, the synthetic method is superior because its end is not simply the discovery of first principles, but the knowledge of things, that is, effects, by means of causes. Furthermore, Zabarella adds, if the principles were already known, the analytic method would be useless.

Zabarella's entire logical system, however, is grounded on the analytic method. He posits two kinds of analytic method: (1) demonstrative induction, and (2) demonstration from effects ( $a b$ effectu). The analytic method is the necessary but not sufficient condition for acquiring scientific knowledge, most of all because it provides a confused knowledge of a thing's existence. The synthetic method, conversely, demonstrates the cause or essence of the thing and for this reason it is called demonstration propter quid. Unlike other logicians, Zabarella argues for an identification of demonstration propter quid with demonstratio potissima. The latter was usually considered the best kind of demonstration because it gave reasons for both the existence and the cause of a thing, while the former did so only for the cause. However, according to Zabarella, cause cannot be properly demonstrated without existence, and so demonstration propter quid cannot be otherwise than demonstratio potissima.

Scientific knowledge can be acquired only in the conjunction of the analytic and synthetic methods, and in this conjunction lies the entire theory of the regress (regressus). Regress leads the initial confused knowledge to a final, distinct, and perfect knowledge. Take the demonstration ab effectu:

where there is generation, there is matter, in a natural body there is generation,

therefore in a natural body there is matter

The major premise ("where there is generation...") is discovered by induction and therefore provides only confused knowledge; the minor premise ("in a natural body...") comes from observation, so the conclusion can only be known in a confused way. What the demonstration $a b$ effectu proves is not the cause itself, but simply that there must be a cause of the effects, and perhaps the one we have obscurely recognized. This is the first part of the regressus.

In order to acquire knowledge of the effect by means of a distinct knowledge of the cause, and to demonstrate that the cause discovered by the analytic method is that correctly pertaining to the effect, Zabarella requires a "mental examination." Mental examination, or consideration, is constituted by two moments. The first recognizes the existence of the effect's cause and prepares for the discovery of that cause's essence or nature, while the second compares the cause (known only confusedly) with the effect. If the comparison is successful, we can say that the causes and principles discovered initially in a confused way are the genuine causes and principles of the effects, now known perfectly. This is the final moment of the regressus and it coincides with the demonstratio potissima - that is, with the acquisition of scientific knowledge (Berti 2009; Mikkeli 2010).

\section{Impact and Legacy}

Zabarella's philosophy had a profound impact on the development of logic in the seventeenth century, especially in Britain and Germany. As 
regards direct influence, in the seventeenth century the British Isles saw his works adopted by the universities of Cambridge, Oxford, Glasgow, St. Andrews, Aberdeen, Edinburgh, and Dublin. British logical textbooks such as those of John Argall (1605) and Richard Crakanthorpe (1622), which were far more detailed and advanced than Ramist textbooks, were largely inspired by Zabarella. Griffin Powell's Analysis analyticorum posteriorum sive librorum Aristotelis de demonstratione (1594) and John Flavel's Tractatus de demonstratione methodicus et polemicus (1619) clearly evince Zabarella's legacy. Respecting the nature of logic and syllogistic, Zabarella plays a major role in Robert Sanderson's Logicae artis compendium (1615), which had a direct influence on John Locke and Isaac Newton. Zabarella's impact on British seventeenth-century logic was additionally mediated by French textbooks such as Philippe Du Trieu's Manuductio ad logicam (1614), and by the publication in Britain of Giulio Pace's Institutiones logicae (1597) and Logicae rudimenta (1612), which were commonly used for logic classes. A special role was reserved for syncretist Bartholomaeus Keckermann, who in his Gymnasium Logicum (1606) mixed Ramist elements with Zabarellean doctrines. Zabarella's logic equally enjoyed widespread success in the German territories. Authors such as Clemens Timpler, Bartholomäus Keckermann, Johann Heinrich Alsted, Georg Gutke, and Abraham Calov show his influence. The early reception of Zabarella's Liber de tribus praecognitis is particularly clear in Alsted's four books of the Philosophia digne restituta (1612). In the second book, devoted to the foundation of the science of the intellectual habits - that is Hexiologia - he clearly draws on Zabarella's ideas. Zabarella contributed to the rise of facultative logic in Protestant countries, especially in the genesis of the disciplines of gnostology and noology. The first important work is Georg Gutke's Habitus primorum principiorum seu Intelligentia (1625), which is re-elaboration of Zabarellean logic. Calov exploits Zabarella's logic and considers gnostology an instrumental discipline which has to do with the habit of the mind knowing an object perfectly, while noology is the science of the mental habit from the use of which the mind acquires the first principles of knowledge (principia cognoscendi) of demonstration. Calov's philosophical elaborations made Zabarella's thought pivotal in the history of the philosophy of mind, exerting a powerful influence on Gottfried Wilhelm Leibniz, the German Enlightenment, and critical philosophy (Sgarbi 2012, 2017, 2018).

\section{Cross-References}

Piccolomini, Francesco

\section{References}

Berti, Enrico. 2009. Nuovi studi aristotelici. IV/1 L'influenza di Aristotele. Antichità, Medioevo e Rinascimento. Brescia: Morcelliana.

Bouillon, Dominique. 2009. L'interprétation de Jacques Zabarella le philosophe. Paris: Garnier.

Dal Pra, Mario. 1966. Un "oratio" programmatica di G. Zabarella. Rivista Critica di Storia della Filosofia 21: 286-291.

Edwards, William F. 1960. The logic of Jacopo Zabarella (1533-1589). PhD dissertation, New York.

Mikkeli, Heikki. 1992. An Aristotelian response to renaissance humanism. Jacopo Zabarella on the nature of arts and sciences. Helsinki: Finnish Historical Society.

Mikkeli, Heikki. 2010. Jacopo Zabarella (1533-1589): The structure and method of scientific knowledge. In Philosophers of the renaissance, 181-191. Washington, DC: The Catholic University of America Press.

Palmieri, Paolo. 2007. Science and authority in Giacomo Zabarella. History of Science 45: 404-427.

Poppi, Antonino. 1972. La dottrina della scienza in Giacomo Zabarella. Padova: Editrice Antenore.

Randall, John H. 1961. The School of Padua and the emergence of modern science. Padova: Editrice Antenore.

Risse, Wilhelm. 1983. Zabarellas Methodenlehre. In Aristotelismo veneto e scienza moderna, 155-172. Padova: Editrice Antenore.

Schmitt, Charles B. 1983. Aristotle and the Renaissance. Cambridge, MA: Harvard University Press. Experience and experiment: A comparison of Zabarella's view with Galileo's in De motu. Studies in the Renaissance 16: $80-138$.

Sgarbi, Marco. 2012. The Aristotelian tradition and the rise of British empiricism. Logic and epistemology in the British Isles (1570-1689). Dordrecht: Springer. 
Sgarbi, Marco. 2017. What does a renaissance Aristotelian look like? From Petrarch to Galilei. HOPOS. The Journal of the International Society for the History of Philosophy of Science 7: 226-245.

Sgarbi, Marco. 2018. Renaissance facultative logic and the workings of the mind: The cognitive turn. In
Philosophy of mind in the late Middle Ages and renaissance, ed. Stephan Schmid, 270-290. London: Routledge.

Vasoli, Cesare. 2011. Jacopo Zabarella e la "natura" della logica. Rivista di Storia della Filosofia 66: 1-22. 